\title{
Characterization of Anaerobic Cellulolytic Bacteria Isolated from Marine Environments
}

\author{
Hideo MiYoshI* \\ (Received September 7, 1977)
}

\begin{abstract}
Eleven strains of anaerobic bacteria capable of digesting cellulose have been isolated from marine environments. These isolates were Gram negative, non-spore-forming, rod-shaped bacteria, and could be divided into three groups: six strains of a yellow-pigmented group; three strains of a non-pigmented group; and two strains of a light brown-pigmented group. For characterizing the isolates detailed examinations were carried out with representative isolates: yellow-pigmented strain $\mathrm{Y}$; light brown-pigmented strain B; and non-pigmented strain W. No essential difference was found between these strains in respect to biochemical reactions, inorganic requirements, or major organic acid accumulated in the cultures. Some differences were noted in the spectra of carbon and nitrogen sources as well as in the patterns of vitamin requirements. The strains did not correspond with any previously described species, and could probably be considered as new species belonging to genus Bacteroides.
\end{abstract}

There were a relatively large number of anaerobic cellulolytic bacteria in recent marine sediments especially in coastal regions of the sea ${ }^{11}$, and the biological degradation of cellulose by the organisms seemed unable to be disregarded in view of the carbon cycle of the coastal sea.

A survey of some literatures revealed that no detailed information is available on the characteristics of the anaerobic cellulolytic bacteria. Therefore, attempts were made to isolate anaerobic cellulolytic bacteria of marine origin, and the representative strains purely isolated have been characterized by morphological, biochemical, and cultural features. The present paper describes the results of this investigation.

\section{Methods}

\section{Media}

The medium used for isolation and maintenance (referred to as medium 1) was identical in composition to that reported earlier ${ }^{1 \prime}$. The same medium without $0.2 \%$ cellobiose and filter paper (referred to as medium 2) was employed to clarify the influences of sulfide concentration and temperature on growth. The basal medium used for most of the tests for nutritional requirements (referred to as medium 3) contained the following ingredients $(\mathrm{g} / l): \mathrm{NaCl}, 24 \mathrm{~g} ; \mathrm{MgCl}_{2} \cdot 6 \mathrm{H}_{2} \mathrm{O}, 11 \mathrm{~g}$; $\mathrm{Na}_{2} \mathrm{SO}_{4}, 4 \mathrm{~g} ; \mathrm{CaCl}_{2}, 1.5 \mathrm{~g} ; \mathrm{KCl}, 0.5 \mathrm{~g} ; \mathrm{NH}_{4} \mathrm{Cl}, 2 \mathrm{~g}$; $\mathrm{FeCl}_{3}, 5 \mathrm{mg} ; \mathrm{Na}_{2} \mathrm{HPO}_{4}, 10 \mathrm{mg} ; \mathrm{Na}_{2} \mathrm{CO}_{3}, 4 \mathrm{~g}$; $\mathrm{Na}_{2} \mathrm{~S} \cdot 9 \mathrm{H}_{2} \mathrm{O}, 0.5 \mathrm{~g}$; vitamin-free casamino acids
(Difco), $0.5 \mathrm{~g}$; cellobiose, $2 \mathrm{~g}$; cysteine $\cdot \mathrm{HCl} \cdot \mathrm{H}_{2} \mathrm{O}$, $0.5 \mathrm{~g}$; $p$-aminobenzoic acid, $1 \mathrm{mg}$; biotin, $10 \mu \mathrm{g}$; cobalamin, $10 \mu \mathrm{g}$; choline $\cdot \mathrm{HCl}, 1 \mathrm{mg}$; folic acid, $10 \mu \mathrm{g}$; niacin, $1 \mathrm{mg}$; Ca-pantothenate, $1 \mathrm{mg}$; pyridoxal, $1 \mathrm{mg}$; riboflavin, $1 \mathrm{mg}$; thiamine, $1 \mathrm{mg}$. The first 5 components of the medium mentioned above were added to make artificial seawater. For the inorganic requirement tests of strains B and $Y$, casamino acids-free medium 3 (referred to as medium 4) was employed. Medium 1 enriched with casamino acids $(0.5 \mathrm{~g} / l)$ and biotin $(10 \mu \mathrm{g} / l)$ in place of peptone (referred to as medium 5) was employed to obtain a growth curve and some additional information during growth.

These media were dispensed under a gas phase of oxygen-free $\mathrm{CO}_{2}$ in $10 \mathrm{ml}$ amounts in $16 \mathrm{~mm}$ wide acid-cleaned borosilicate test tubes, capped with butyl rubber plugs and sterilized at $120^{\circ} \mathrm{C}$ for $20 \mathrm{~min}$.

\section{Isolation}

An appropriate dilution of marine mud was inoculated into medium 1 , and incubated at $30^{\circ} \mathrm{C}$. The tube showing visual digestion of filter paper was selected, and transferred to molten medium 2 enriched with $1.5 \%$ agar and $0.5 \%$ acid-treated cellulose. $^{2)}$ Then the inoculated tube was rolled in cold water until the medium was set in a thin layer on the tube wall, and incubated at $30^{\circ} \mathrm{C}$. The colony which showed a clear area was transferred to medium 1 to ensure filter paper disintegration. The isolate was further purified by

\footnotetext{
* Faculty of Agriculture, Kochi Univ., Nangoku, Japan (三好英夫：高知大学榓学部).
} 
repeating the procedures described above.

\section{Routine Tests for the Identification of Bacteria}

The isolates were characterized biochemically by routine tests according to the Anaerobe Laboratory Manual ${ }^{31}$, but the media employed here were prepared by using aged seawater, and enriched with equivalent amount of cellobiose in place of glucose.

\section{Growth Experiment}

About $0.1 \mathrm{ml}$ of actively-growing culture was employed as inoculum. Inoculation was done under a gas phase of oxygen-free $\mathrm{CO}_{2}$, and incubation was carried out at $30^{\circ} \mathrm{C}$ for 20 days. The growth yields were determined by measuring the optical density at $660 \mathrm{~m} \mu$ in a cuvette of $10 \mathrm{~mm}$ light-path. In some cases a few droplets of $6 \mathrm{~N}$ $\mathrm{HCl}$ were added to a culture for dissolving inorganic precipitates at the end of cultivation.

\section{Chemical Analyses}

Protein was determined according to the method of LOWRY et al. ${ }^{4 !}$ Sugar was determined by the anthrone method ${ }^{51}$. Organic acids were extracted with ether and analyzed in the same manner as described by CARLSSON ${ }^{6}$.

\section{Bacterial Counting}

Bacterial counting was carried out in the same manner as described by LUMPKMns and ARVESON ${ }^{7 !}$.

\section{Measurement of Eh}

Redox potential $(E h)$ of medium was measured by using redox meter just before inoculation.

\section{Results and Discussion}

Eleven strains of non-spore-forming, Gram negative rods, capable of digesting cellulose were purely isolated from marine sediments. Based on preliminary experiments, these isolates were divided into the following 3 groups: 6 strains of a yellow-pigmented group; 3 strains of a nonpigmented group; and 2 strains of a light brownpigmented group. In most anaerobic marine environments the yellow-pigmented group was predominant and the light brown-pigmented or the non-pigmented group was found sporadically. The yellow-pigmented strains grew well and showed active digestion of cellulose. The light brown-pigmented strains grew slowly and the digestion of cellulose was not so rapid as compared with the yellow-pigmented strains. The non-pigmented strains showed very slow and scanty growth, and the strains did not digest cellulose completely unless a microbial contamination occurred in the medium.

The morphological, cultural, and biochemical characteristics of the representative strains belonging to each group are described in Table 1.

There are many reports dealing with the pure strain of anaerobic cellulolytic bacteria isolated

Table 1. Morphological, cultural, and biochemical properties of representative strains of marine cellulolytic anaerobes

\begin{tabular}{|c|c|c|c|}
\hline Property & $\begin{array}{l}\text { Light brown-pigmented } \\
\text { strain } B\end{array}$ & $\begin{array}{l}\text { Yellow-pigmented } \\
\text { strain } Y\end{array}$ & $\begin{array}{l}\text { Non-pigmented } \\
\text { strain W }\end{array}$ \\
\hline \multicolumn{4}{|l|}{ Morphological characteristics } \\
\hline Form & Rod with round ends & Rod with round ends & Rod with round ends \\
\hline Size & $0.7 \mu \times 3-7 \mu$ & $0.7 \mu \times 3-7 \mu$ & $0.5 \mu \times 2-7.5 \mu$ \\
\hline Motility & Motile & Non-motile & Non-motile \\
\hline Gram stain & Negative & Negative & Negative \\
\hline \multicolumn{4}{|l|}{ Cultural characteristics } \\
\hline $\begin{array}{l}\text { Seawater cellobiose agar } \\
\text { slant }\end{array}$ & $\begin{array}{l}\text { Smooth, glistening, } \\
\text { beaded }\end{array}$ & $\begin{array}{l}\text { Smooth, glistening, } \\
\text { filiform }\end{array}$ & $\begin{array}{l}\text { Smooth, glistening, } \\
\text { effuse }\end{array}$ \\
\hline Filter paper degradation & $\begin{array}{l}\text { Fiber separated on slight } \\
\text { agitation }\end{array}$ & $\begin{array}{l}\text { Fiber separated on slight } \\
\text { agitation }\end{array}$ & $\begin{array}{l}\text { Macerative rather than } \\
\text { lytic }\end{array}$ \\
\hline \multicolumn{4}{|l|}{ Biochemical characteristics } \\
\hline Gelatin digestion & Slow liquefaction & Slow liquefaction & - \\
\hline Nitrate reduction & Negative & Negative & Negative \\
\hline Voges-Proskauer test & Negative & Negative & Negative \\
\hline Indol production & Negative & Negative & Negative \\
\hline Catalase & Negative & Negative & Negative \\
\hline
\end{tabular}


from intestine ${ }^{81}$, rumen ${ }^{9,10 !}$, soil ${ }^{10,11 !}$, and sewage sludge ${ }^{101}$, and simplified descriptive charts of some marine cellulolytic anaerobes were included in

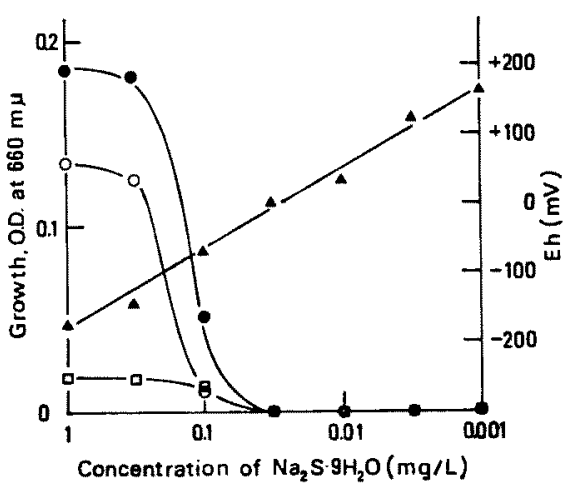

Fig. 1. Effects of the concentrations of reducing agent on the growth of anaerobic cellulolytic bacteria. Symbols: $O$, strain $B ; \square$, strain $W$; e, strain $Y ; \Delta$, oxidation-reduction potential.

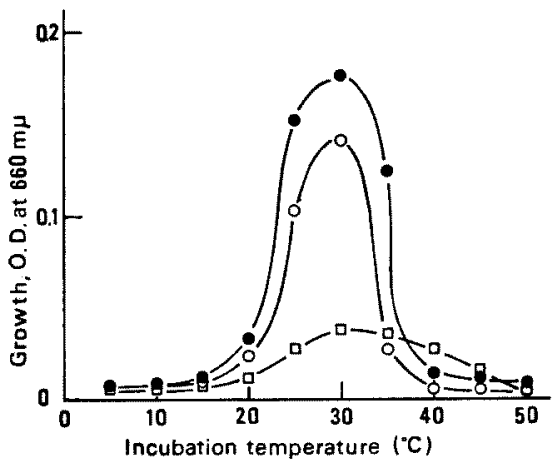

Fig. 2. Effects of incubation temperatures on the growth of anaerobic cellulolytic bacteria. Symbols: O, strain B; 9 , strain Y; $\square$, strain W.

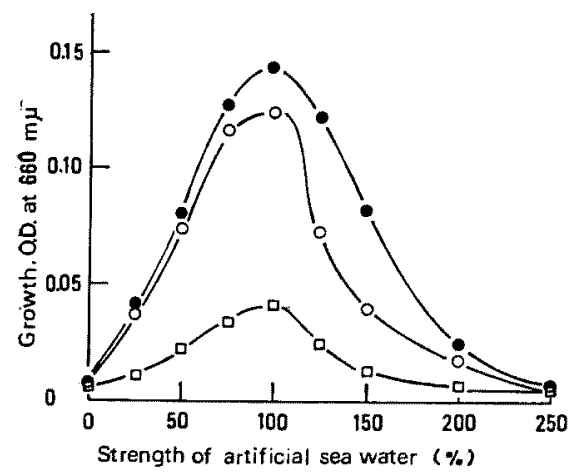

Fig. 3. Effects of the strengths of artificial seawater on the growth of anaerobic cellulolytic bacteria. Symbols: $O$, strain B; $\square$, strain $\mathrm{W} ; \bullet$, strain $\mathrm{Y}$. a paper by LisToN ${ }^{12 !}$. The new isolates, strains $B$, $W$, and $Y$, seem to be somewhat different from the cellulolytic anaerobes described in the early reports. The taxonomic position of the isolates will be discussed later.

The effects of varying concentrations of $\mathrm{Na}_{2} \mathrm{~S}$. $9 \mathrm{H}_{2} \mathrm{O}$ on the growth of strains $\mathrm{B}, \mathrm{W}$, and $\mathrm{Y}$ are shown in Fig. 1. The approximate levels of $E h$ of the media are also illustrated in the same figure. Detectable growth of these strains was found only when the concentration of $\mathrm{Na}_{2} \mathrm{~S} \cdot 9 \mathrm{H}_{2} \mathrm{O}$ was higher than $0.03 \%$; the upper limits of $E h$ to permit the growth of these strains were in the range of -100 to $0 \mathrm{mV}$. That is, these strains could grow only in the media showing complete decolouration of resarfin. Therefore, these strains are fastidious in their requirements for anaerobiosis just like most strains of cellulolytic rumen bacteria.

The effects of temperature on the growth of strains B, W, and $Y$ are shown in Fig. 2. These strains were all mesophilic organisms showing the maximal growth rate at $c a .30^{\circ} \mathrm{C}$, and appreciable growth of strains $\mathrm{B}$ and $\mathrm{Y}$ was detected in the range of $20^{\circ}$ to $30^{\circ} \mathrm{C}$, but detectable growth of strain $\mathrm{W}$ occurred within the range of $20^{\circ}$ to $45^{\circ} \mathrm{C}$.

The growth yields of strains $B, Y$, and $W$ at varying strengths of artificial seawater in medium 3 are shown in Fig. 3. The extreme concentrations of artificial seawater which allowed detectable growth of these strains were $25 \%$ and $200 \%$. The maximal growth occurred at normal concentration of artificial seawater. Therefore, these strains seem to be placed in the same category with slight halophile which occurred ubiquitously in marine environments.

The growth yields in modified medium 4 (for strains $B$ and $Y$ ) or medium 3 (for strain $W$ ) each of which contained reduced concentrations of an inorganic ingredient are shown in Table 2. Strictly speaking, the inorganic requirement of strain $\mathrm{W}$ was not conclusive due to the presence of inorganic components in casamino acids. But significant reduction of growth yields of each test strain was observed by lowering the added concentration of $\mathrm{NaCl}, \mathrm{MgCl}_{2}, \mathrm{CaCl}_{2}, \mathrm{KCl}$, or $\mathrm{Na}_{2} \mathrm{HPO}_{4}$, but $\mathrm{FeCl}_{3}$ and $\mathrm{Na}_{2} \mathrm{SO}_{4}$ could be omitted from the test media without interfering with the cell yields. Anyhow, so far as these data were concerned, sodium, magnesium, calcium, potassium, and phosphate ions seem to be essential for the growth of these three strains. The requirement of such ions is not so unique for marine bacteria. 
Table 2. Growth yields of marine anaerobic cellulolytic bacteria in the media having reduced concentrations of inorganic components

\begin{tabular}{|c|c|c|c|c|}
\hline \multirow{2}{*}{ Component } & \multirow{2}{*}{$\begin{array}{l}\text { Concen- } \\
\text { tration } \\
\text { added } \\
(\mathrm{g} / l)\end{array}$} & \multicolumn{3}{|c|}{ Growth, O.D. at $660 \mathrm{~m} \mu$} \\
\hline & & $\underset{\mathbf{B}}{\text { Strain }}$ & $\underset{W}{\text { Strain }}$ & $\underset{\mathrm{Y}}{\text { Strain }}$ \\
\hline $\mathrm{NaCl}$ & $\begin{array}{l}2.4 \\
0.24 \\
0\end{array}$ & $\begin{array}{l}0.084 \\
0.087 \\
0.088\end{array}$ & $\begin{array}{l}0.017 \\
0.015 \\
0.015\end{array}$ & $\begin{array}{l}0.149 \\
0.092 \\
0.083\end{array}$ \\
\hline $\mathrm{MgCl}_{2} \cdot 6 \mathrm{H}_{2} \mathrm{O}$ & $\begin{array}{l}1.1 \\
0.11 \\
0\end{array}$ & $\begin{array}{l}0.208 \\
0.027 \\
0.002\end{array}$ & $\begin{array}{l}0.023 \\
0.012 \\
0.016\end{array}$ & $\begin{array}{l}0.187 \\
0.061 \\
0.004\end{array}$ \\
\hline $\mathrm{Na}_{2} \mathrm{SO}_{4}$ & $\begin{array}{l}0.4 \\
0.04 \\
0\end{array}$ & $\begin{array}{l}0.193 \\
0.172 \\
0.186\end{array}$ & $\begin{array}{l}0.027 \\
0.025 \\
0.026\end{array}$ & $\begin{array}{l}0.198 \\
0.200 \\
0.185\end{array}$ \\
\hline $\mathrm{NH}_{4} \mathrm{Cl}$ & $\begin{array}{l}0.2 \\
0.02 \\
0\end{array}$ & $\begin{array}{l}0.101 \\
0.065 \\
0.018\end{array}$ & E & $\begin{array}{l}0.188 \\
0.084 \\
0.022\end{array}$ \\
\hline $\mathrm{CaCl}_{2}$ & $\begin{array}{l}0.15 \\
0.015 \\
0\end{array}$ & $\begin{array}{l}0.310 \\
0.260 \\
0.009\end{array}$ & $\begin{array}{l}0.022 \\
0.015 \\
0.016\end{array}$ & $\begin{array}{l}0.187 \\
0.174 \\
0.007\end{array}$ \\
\hline $\mathrm{KCl}$ & $\begin{array}{l}0.05 \\
0.005 \\
0\end{array}$ & $\begin{array}{l}0.125 \\
0.027 \\
0.022\end{array}$ & $\begin{array}{l}0.021 \\
0.017 \\
0.017\end{array}$ & $\begin{array}{l}0.161 \\
0.013 \\
0.013\end{array}$ \\
\hline $\mathrm{Na}_{2} \mathrm{HPO}_{4}$ & $\begin{array}{l}0.001 \\
0.0001 \\
0\end{array}$ & $\begin{array}{l}0.055 \\
0.021 \\
0.010\end{array}$ & $\begin{array}{l}0.019 \\
0.018 \\
0.016\end{array}$ & $\begin{array}{l}0.039 \\
0.015 \\
0.019\end{array}$ \\
\hline $\mathrm{FeCl}_{3}$ & $\begin{array}{l}0.0005 \\
0.00005 \\
0\end{array}$ & $\begin{array}{l}0.200 \\
0.204 \\
0.188\end{array}$ & $\begin{array}{l}0.026 \\
0.028 \\
0.028\end{array}$ & $\begin{array}{l}0.184 \\
0.185 \\
0.201\end{array}$ \\
\hline Control (comp & lete) & 0.203 & 0.028 & 0.192 \\
\hline
\end{tabular}

The availability of organic compounds as the sole source of carbon and energy was examined by using medium 3 as basal medium. The results are described in Table 3. The growth of strain B was supported at the expense of xylose, glucose, cellobiose, or maltose. The growth of strain $\mathrm{W}$ occurred on formate, acetate, or cellobiose, but strain Y could utilize only cellobiose out of twenty organic compounds tested. The addition of peptone, yeast extract, or beef extract in the concentration of $0.1 \%$ had no essential influence on the spectra of carbon and energy sources.

Considering the ubiquitous occurrence of cellulolytic anaerobes in coastal sediments, the restricted spectra are of interest for indirect evidence that coastal sediments are contaminated so universally and successively by cellulosic materials.

The availability of nitrogen compounds as a sole source of nitrogen was examined with medium 3 as basal medium. The results are shown in Table 4. Heavy or appreciable growth of strains $B$ and $Y$ was obtained with $\mathrm{NH}_{4} \mathrm{Cl}$, asparagine, peptone, tryptone, or casamino acids, and little or no growth
Table 3. Carbon sources utilized for the growth of marine anaerobic cellulolytic bacteria

\begin{tabular}{lccc}
\hline Carbon source & \multicolumn{3}{c}{ Growth, O.D. at $660 \mathrm{~m} \mu$} \\
\cline { 2 - 4 }$(5 \mathrm{~g} / l)$ & Strain B & Strain W & Strain Y \\
\hline Acetate & 0.006 & 0.009 & 0.000 \\
Citrate & 0.012 & 0.004 & 0.002 \\
Formate & 0.010 & 0.011 & 0.001 \\
Fumarate & 0.013 & 0.002 & 0.004 \\
Lactate & 0.013 & 0.004 & 0.002 \\
Propionate & 0.013 & 0.001 & 0.000 \\
Pyruvate & 0.006 & 0.002 & 0.001 \\
Cellobiose & 0.071 & 0.025 & 0.456 \\
Fractose & 0.013 & 0.001 & 0.004 \\
Galactose & 0.022 & 0.004 & 0.002 \\
Glucose & 0.046 & 0.004 & 0.002 \\
Lactose & 0.018 & 0.004 & 0.002 \\
Maltose & 0.030 & 0.000 & 0.002 \\
Mannose & 0.014 & 0.004 & 0.000 \\
Saccharose & 0.011 & 0.000 & 0.000 \\
Starch & 0.013 & 0.001 & 0.004 \\
Xylose & 0.051 & 0.001 & 0.003 \\
Glycerol & 0.010 & 0.000 & 0.000 \\
Mannitol & 0.009 & 0.004 & 0.003 \\
Sorbitol & 0.013 & 0.003 & 0.004 \\
None & 0.014 & 0.004 & 0.003 \\
\hline & & & \\
\hline
\end{tabular}

Table 4. Nitrogen sources utilized for the growth of marine anaerobic cellulolytic bacteria

\begin{tabular}{lccc}
\hline \multirow{2}{*}{$\begin{array}{c}\text { Nitrogen } \\
\text { source } \\
(2 \mathrm{~g} / l)\end{array}$} & \multicolumn{3}{c}{ Growth, O.D. at $660 \mathrm{~m} \mu$} \\
\cline { 2 - 4 } & Strain B & Strain W & Strain Y \\
\hline $\mathrm{NaNO}_{2}$ & 0.014 & 0.016 & 0.011 \\
$\mathrm{NaNO}_{3}$ & 0.015 & 0.012 & 0.012 \\
$\mathrm{NH}_{4} \mathrm{Cl}$ & 0.146 & 0.018 & 0.159 \\
Asparagine & 0.079 & 0.018 & 0.051 \\
Na-glutamate & 0.013 & 0.021 & 0.013 \\
Casamino acids & & & \\
$\quad$ (Difco) & 0.181 & 0.035 & 0.081 \\
Peptone (Difco) & 0.058 & 0.080 & 0.036 \\
Tryptone (Difco) & 0.064 & 0.065 & 0.030 \\
None & 0.016 & 0.018 & 0.013 \\
\hline
\end{tabular}

took place with $\mathrm{NaNO}_{2}, \mathrm{NaNO}_{3}$, or Na-glutamate. On the other hand, lower but still appreciable growth of strain W was supported only with complex nitrogen sources such as tryptone, casamino acids, and peptone.

Attempts were made to determine the vitamin requirements of strains $B, W$, and $Y$ by omitting individual vitamins from medium 3 . The results are shown in Table 5. Strains B and Y uniformly required biotin for good growth, and there was no evidence of requirements for other vitamins, and $1 \mu \mathrm{g} / l$ of biotin was enough to give reproducible heavy growth for these strains. Whereas, 
Table 5. Vitamin requirements of marine anaerobic cellulolytic bacteria

\begin{tabular}{lccc}
\hline \multirow{2}{*}{ Vitamin } & \multicolumn{4}{c}{ Requirement } \\
\cline { 2 - 4 } & Strain B & Strain W & Strain Y \\
\hline p-Aminobenzoic acid & - & + & - \\
Biotin & + & + & + \\
Cobalamin & - & - & - \\
Choline & - & - & - \\
Folic acid & - & + & - \\
Niacin & - & - & - \\
Pantothenic acid & - & - & - \\
Pyridoxal & - & + & - \\
Riboflavin & - & - & - \\
Thiamine & - & - & - \\
\hline
\end{tabular}

Symbols: + , essential or stimulatory for growth; - , not essential.

the growth of strain $\mathrm{W}$ was stimulated by $p$ aminobenzoic acid, biotin, folic acid, and pyridoxal.

Typical growth curves for strains $B$ and $Y$ on medium 5 are illustrated in Fig. 4. The weight losses of cellulose and the accumulations of soluble protein and sugar during growth are also shown in the same figure. The continuous but slow growth of strains $B$ and $Y$ was observed in the first 15-20 days of incubation. Thereafter no appreciable grwoth occurred by further incubations. On the other hand, discernible losses of cellulose and significant accumulations of soluble protein and sugar were noted after the first 12-14 days of incubation. Thereafter the losses of cellulose and the accumulations of soluble protein and sugar showed continuous increases. Soluble protein in the medium should include excreted cellulase, and the levels of soluble protein seemed to be roughly correlated with the losses of cellulose.

On the other hand, the accumulated sugar was regarded as a transient metabolite and seemed to be converted gradually into final products such as organic acids and $\mathrm{CO}_{2}$. In fact, as shown in Fig. 5, organic acids were detected in the cultures. Irrespective of the test strain, the major organic acid detected by the chromatographic method was acetic acid. The fact may serve as an important adjunct in characterizing the isolates.

Taking all the available data into account, the isolated strains did not correspond with any previously described species $^{3,13}$, and the strains. could probably be considered as new organisms. belonging to genus Bacteroides ${ }^{3,141}$, but the detailed characteristics of the strains are not identical to those cited in the descriptions of genus Bac-
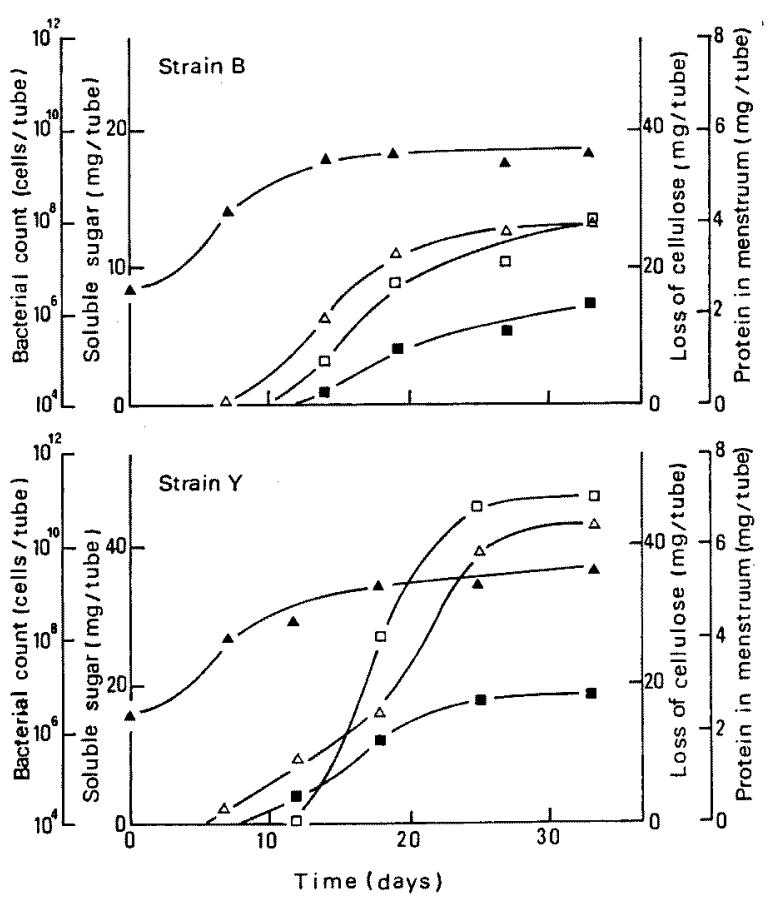

Fig. 4. Growth curves of marine anaerobic cellulolytic bacteria and accumulation of sugar, excretion of protein, and loss of cellulose in the course of the growth. Symbols: $\Delta$, bacterial count; $\triangle$, loss of cellulose; $\mathbf{E}$, sugar; $\square$, protein. 

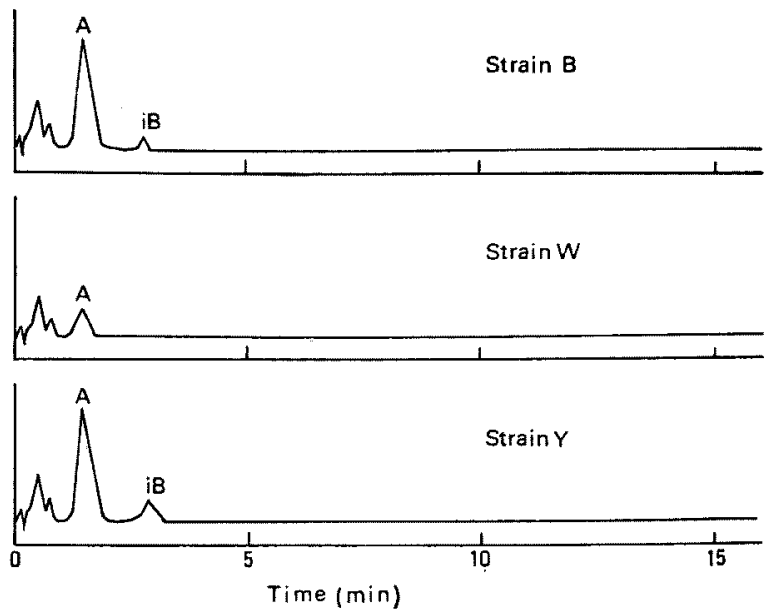

Fig. 5. Chromatograms of organic acids accumulated in the cultures of marine anaerobic cellulolytic bacteria. Symbols: A, acetic acid; iB, isobutyric acid.

teroides $^{3,13)}$. Especially the fact that no accumulation of succinic acid occurred in the cultures of strains $B, W$, and $Y$ seems to be important. Therefore, further studies are needed to draw a final conclusion as to whether strains $\mathrm{B}, \mathrm{W}$, and $\mathrm{Y}$ belong to genus Bacteroides or not.

\section{References}

1) H. Mryoshi: Res. Rep. Kochi Univ., 26(3), 1-6 (1977).

2) J. W. Green: in "Methods in Carbohydrate Chemistry" (ed. by R. L. WhistLer), Vol. 3, Academic Press, New York, 1963, pp. 95.

3) L. V. Holdeman and W. E. Moore (ed.): Anaerobe Laboratory Manual, 3rd ed., Virginia Polytechnic Institute and State University Anaerobe Laboratory, Blacksburg, Va., 1975, pp. 1-132.

4) O. H. Lowry, N. J. Rosenborough, A. L. Fark, and R. J. Randall: J. Biol. Chem., 193, 265 (1951).
5) J. D. H. Strickland and T. R. Parsons: A Practical Handbook of Seawater Analysis, Fisheries Research Board of Canada, Ottawa, 1968, pp. 231-234.

6) J. Carl.sson: Appl. Microbiol., 25, 287-289 (1973).

7) E. D. Lumpkins and J. S. Arveson: Appl. Microbiol., 16, 433-434 (1968).

8) M. E. Davies: J. Appl. Bact., 27, 373-378 (1964).

9) R. E. Hungate: The Rumen and its Microbes, Academic Press, New York, 1966, pp. 36-59.

10) R. E. Hungate: Bact. Rev., 14, 1-49 (1950).

11) F. A. SKInNer: J. Gen. Microbiol., 22, 539-554 (1960).

12) J. Liston: Bull. Misaki Marine Biol. Inst., Kyoto Univ., No. 12, 97-104 (1968).

13) R. E. Buchanan and N. E. Gibbons (ed.): Bergey's Manual of Determinative Bacteriology, 8th ed., Williams and Wilkins Company, Baltimore, Md., 1974, pp. $384-404$.

14) P. D. Ellner, P. A. Granato and C. B. May: Appl. Microbiol., 26, 904-913 (1973). 